\title{
Clearinghouse loan certificates as interbank loans in the United States, I860-I9I3
}

\author{
CHRISTOPHER HOAG \\ Trinity College, Hartford
}

\begin{abstract}
Before the founding of the Federal Reserve, bank clearinghouse associations served as an emergency lending facility during the National Bank Era (1863-I9I3). This article clarifies the operation of clearinghouse loan certificates during panic periods. If clearinghouse loan certificates do not circulate among the general public, then they bear similarities to interbank loans among clearinghouse member banks. In general, the central clearinghouse organization does not act alone as a lender of last resort to make loans from the central clearinghouse to individual member banks.
\end{abstract}

Keywords: bank, lender of last resort, clearinghouse, loan certificates

JEL classification: G2I, G28, N2I

In the absence of a central bank, the American banking market developed private solutions to financial crises during the nineteenth century (Timberlake I984; Gorton I985). Clearinghouse actions and bank cooperation could improve the stability of financial markets during recurrent crises (Sprague I9Io; Wicker 2000). Moen and Tallman (2000), Hoag (20II) and Jaremski (20I5) evaluate the question of whether clearinghouse membership improved outcomes for banks during financial crises.

Clearinghouse loan certificates served as one of the most important pieces of the defensive architecture (Cannon I908; Hoag 20I2; Tallman and Moen 20I2; Moen and Tallman 2013; Hoag 2015). Despite the growing literature on clearinghouses and their actions during financial crises and the careful description by Cannon (I908), some points about the mechanics of loan certificates are not necessarily well documented, in particular their redemption. We explore these features of clearinghouse loan certificates to draw conclusions about the function of bank clearinghouses during financial crises.

C. Hoag, Trinity College, 300 Summit Street, Hartford, CT 06 I06, USA; Email: Christopher.Hoag@ trincoll.edu. Thanks to three anonymous referees for their comments as well as to the editor for helpful guidance. Thanks also to Ms Mirjana Orovic for allowing me to collect the data. The usual disclaimer applies. 
For the purpose of this article, we focus on the particular case of large, historic clearinghouses that did not issue clearinghouse loan certificates to the general public. In particular, we consider primarily the New York Clearing House, the largest and oldest clearinghouse in the United States. Further, this article does not comment on the ability of clearinghouses to issue (potentially illegal or at least taxable) scrip currency to banks for distribution to the general public. Almost exclusively before 1907 (there were only a few exceptions in I893), bank clearinghouses issued no special currency to the general public for use during crises. Even in 1907, several of the largest and most reputed clearinghouses such as New York, Boston and Philadelphia did not issue such scrip (Andrew I908).

This article investigates the role of the central clearinghouse organization as an emergency lending facility. Some of the previous literature characterized clearinghouse loan certificates as direct lending from a lender of last resort, the central clearinghouse organization, to individual member banks. Instead, this article documents the argument that when clearinghouse loan certificates were not permitted to be used outside the clearinghouse, they have features that are similar to interbank loans among the member banks. While clearinghouse loan certificates are not exactly interbank loans (in particular, member banks were not permitted to choose whether to accept loan certificates as a substitute for currency in the settlement of the daily clearings), loan certificates replicate the cash flows of interbank loans, and viewing the cash flows of the loan certificates as interbank loans helps us to understand bank clearinghouse operations during crises. In particular, the central clearinghouse does not act alone as a lender of last resort. Each use of the loan certificate required another member bank to refrain from collecting a payment of reserves. This individual bank that does not collect reserves essentially makes a temporary interbank loan. Further, the central clearinghouse did not retain the interest paid by banks that borrowed loan certificates, so the central clearinghouse was not a lender. The interest on the loan certificate accrued to the individual lending bank. Moreover, while the associated members did jointly guarantee the loan certificates, this guarantee need not imply that the clearinghouse organization served as a central counterparty to all transactions associated with the loan certificates. This article does not preclude the possibility of central clearinghouse organizations making loans to individual member banks; it is just that the device of clearinghouse loan certificates was not in itself a way for central clearinghouses to fund loans.

The comparison of clearinghouse loan certificates to interbank loans produces implications for the study of bank behavior during financial crises. First, one might be tempted treat borrowing loan certificates from a clearinghouse as individual bank borrowing from a lender of last resort. While we can evaluate the behavior of individual banks as borrowing from a lender of last resort during crises, we should be cognizant of its limitations. In particular, some banks that borrowed loan certificates may have held more loan certificates than they borrowed, so they were net lenders to the system and provided liquidity to other banks. Classifying such net lenders as borrowers would mischaracterize their activity. Comparing clearinghouse 
loan certificates to interbank loans implies that we should concentrate on net borrowing or truncated borrowing (the positive part of borrowing after deducting lending) rather than borrowing alone (Hoag 20I5). Second, the comparison of clearinghouse loan certificate operations to interbank loans calls for more theoretical and empirical analysis of the incentives of the system to explain the cross-sectional incidence of borrowing. Instead of a single political entity of a clearinghouse making loans to banks, the funding of loan certificates by individual banks might lead to suboptimal cooperation dynamics that require additional study. For example, healthy and conservative banks might prefer to cooperate less under a loan certificate system if riskier banks regularly required larger borrowings of loan certificates. Hoag (2012) argues that moral hazard did not drive loan certificate borrowing in I 893 .

Note that even if central clearinghouse organizations were not using loan certificates to make loans to individual banks directly, comparing clearinghouse loan certificates to interbank loans does not detract from the quasi-central bank operations of clearinghouses. The literature celebrates clearinghouses as adopting several of the functions of modern a central bank, such as bank monitoring, requiring higher fractions of bank reserves than national regulators, and fighting financial crises (Sprague I9I0; Gorton I985; Gorton and Mullineaux I987; Wicker 2000). These activities persisted regardless of the interpretation of clearinghouse loan certificates. Even if the central clearinghouse did not make loans on its own through the device of loan certificates, clearinghouses did serve as an emergency lending facility by developing the structure that facilitated loans to banks during crises.

Understanding the mechanics of clearinghouse loan certificates requires knowledge of bank clearing. Unlike Richardson (2007) and James and Weiman (2010), who consider check clearing and the correspondent relationship across cities, we focus on clearing in one city. Figure 5.I of James and Weiman (2005) depicts the checkclearing process. Consider an example rooted in historical experience but not necessarily representing the actual development of clearinghouse history. Before the establishment of clearinghouses, banks would have to clear checks by hand. Suppose a town has two banks, Bank A and Bank B. Depositor I deposits \$Ioo in an account at Bank A. Now imagine that Depositor I writes a check for $\$$ IOO and hands it to Depositor 2 who has an account at Bank B. Depositor 2 cashes his check at Bank B, which means that Depositor B endorses the check and gives the check to Bank B, while Bank B pays out $\$$ Ioo in cash to Depositor 2. Now the check gives Bank B a claim on Bank A for $\$$ Ioo. Bank B could hire a porter to take the check to Bank A, and Bank A would pay out \$Ioo to Bank B in exchange for the check. The porter would then have to carry the \$Ioo back to Bank B. After obtaining the check, Bank A would reduce Depositor I's account by $\$$ Ioo. In this way, Depositor I has transferred $\$$ IOo in cash to Depositor 2 even 
though the two depositors exchanged no cash directly. Observe that the process of cashing the check at least temporarily created a liability from Bank A owed to Bank B.

Now imagine that Depositor 3 also has an account at Bank B and writes a $\$ 300$ check on Bank B to Depositor 4, who banks at Bank A and decides to deposit his check at Bank A. Following the logic above, Bank B will owe Bank A the value of the check or $\$ 300$. Thus a porter will have to transport $\$ 300$ in cash from Bank B to Bank A.

But all of this carting money across town creates a lot of traffic by the porter. The porter takes $\$$ IOO from Bank A to Bank B but then must turn around and take $\$ 300$ from Bank B to Bank A. Cash transfers during this period can involve heavy coins. Also, transporting large amounts of money out of the bank creates security concerns. Eventually, to save legwork, some of the porters began to meet in one central location, which cuts down on cross-shipments of cash. Instead of making two shipments, the porter cleverly transfers only the net amount $\$ 300-\$ 100$, or $\$ 200$, from Bank B to Bank A. This innovation represents the essential idea of net clearing: we gather all of the payments from the day and net them (exchange) so as to transfer a smaller quantity of physical money (settlement). Figure I depicts the advantage of clearing, which only requires a transfer of the net payment of $\$ 200$ rather than both payments of $\$ 300$ and $\$$ Ioo.

In a net clearing system, banks exchange all checks drafted on another bank at a central location, the clearinghouse (Cannon I908). Each bank would first record and sum its credits, or checks on other member banks that the bank's customers had deposited. Each bank would then receive the checks written by its own depositors and obtained by the other banks. By summing its debits with each bank, a bank would learn its net payment for the day. Clearing reduces the net payments required by the banks. While the example above includes only two banks, Dunbar (I929) provides a more complicated example of a net clearing system with multiple banks.

With the exchanges accomplished, banks would complete the settlement, or make payments on their net clearing obligation. Net clearing reduces but ordinarily does not eliminate payments among the banks, leaving some payments that cannot be netted: in our example above, the net payment would be \$200. Later in the day after the check exchanges had taken place, banks would deliver the net payments to the clearinghouse where the funds would be transferred from debtor banks to creditor banks. The net payments sum to zero, so the clearinghouse manager simply redistributes funds from debtor banks to creditor banks. The settlement process was expedited by allowing banks to store currency at the clearinghouse. The clearinghouse created special certificates called clearinghouse certificates that represented a claim on actual money stored in a vault and could be used in the settlement. Clearinghouse certificates prevented the need to transfer large sums of money.

Participating in a clearinghouse required risk management procedures. Unless they protest a particular payment, members automatically accept at par the check of any other member institution. Further, even if two banks and the customers of those 
Without clearinghouse
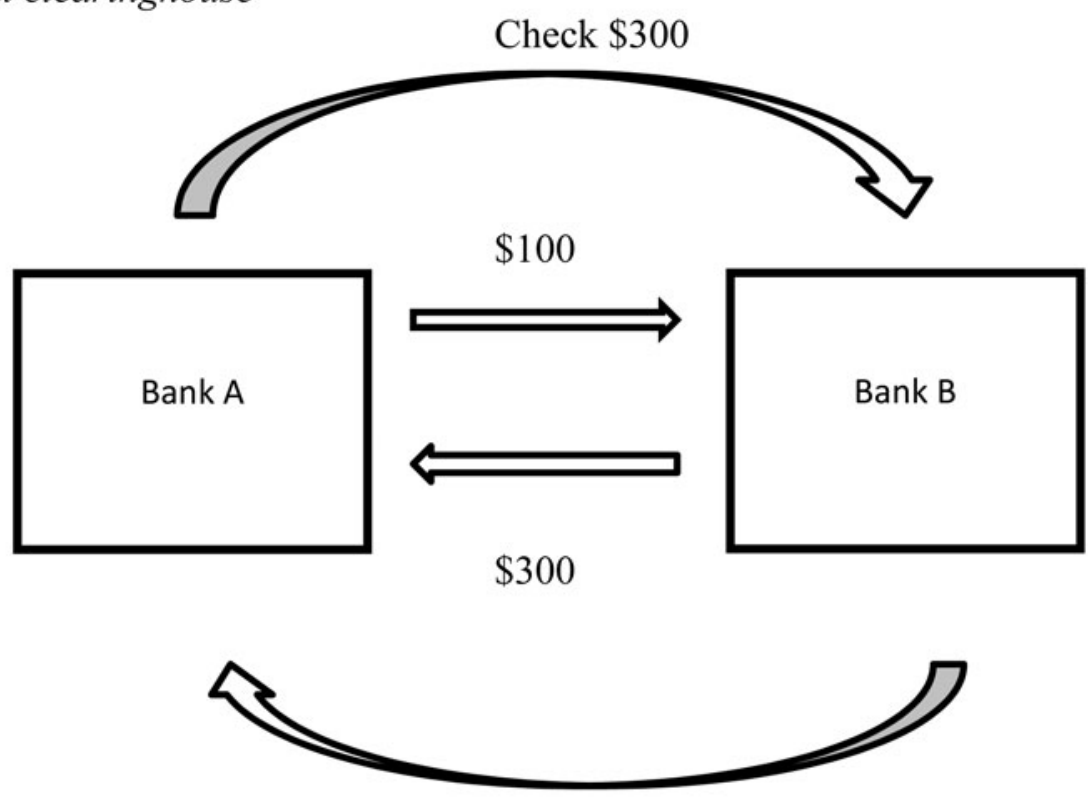

Check $\$ 100$

With clearinghouse

Check $\$ 300$
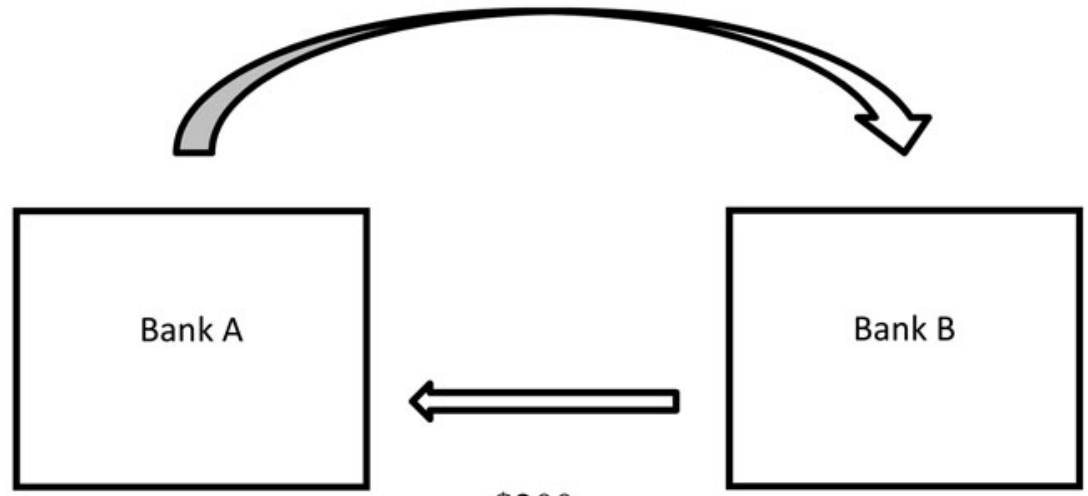

$\$ 200$

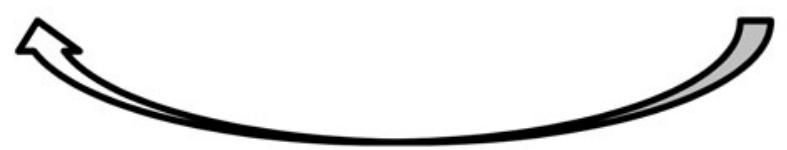

Figure I. The advantage of clearing 
two banks never interacted, the clearing mechanism could still create interbank obligations across the two banks. After the exchanges but before the settlement, a debtor bank could fail, causing a loss to a creditor bank that never accepted a check from the debtor bank. To mitigate this risk, clearinghouses carefully selected potential new members. Once founded, clearinghouses only admitted members by application, and clearinghouses occasionally denied membership to new, smaller banks. In the event of failure, the New York Clearing House required banks exchanging with a defaulting bank to advance cash for use in the settlement (Cannon I908, p. I95). Other clearinghouses would remove the transactions of the defaulting bank and clear without it (Weber 20I2). In general, the central clearinghouse itself carried no liability with respect to the settlement. Clearinghouses were organized as voluntary associations, private organizations that developed their own rules for membership and conduct, and did not guarantee settlement payments as an independent organization. Therefore, member banks would want assurances that all other members were financially sound. Gorton and Mullineaux (I987) emphasize tactics such as bank examinations and monitoring of bank statements that bank clearinghouses employed to ensure the solvency of its members.

Bank clearinghouses coordinated important defenses against financial crises. In the absence of a public lender of last resort, nineteenth-century financial markets suffered a series of financial crises. One consequence of these crises was suspending payments, when banks decided to stop paying out cash over the counter to depositors who wanted to redeem their deposits. Suspension typically required action by bank regulators to take a bank into administration, but when the banks of an entire city agreed to suspend payments, regulators often chose not to prosecute.

Once banks suspended payments during panics, clearinghouses could increase the expansion of loans. Suppose that a bank clearinghouse has two members, Bank A and Bank B. As a result of the crisis, imagine that both banks declare that they suspend payments, and usually this announcement would be made cooperatively at the clearinghouse. Now imagine that the banks want to make loans to their customers who desperately need credit. Often times, banks would lend to brokers or stock market operators who required credit to facilitate securities transactions. Suppose both Bank A and Bank B increase loans by \$Ioo. Bank A lends \$Ioo to Borrower I, and Bank B lends \$IOo to Borrower 2. Remember that under suspension, the borrowers cannot withdraw the money in cash, so the best they can do is write checks. Borrower I could write a check to Depositor IB for $\$$ IOO, and Borrower 2 could write a check to Depositor $2 \mathrm{~A}$ for $\$ \mathrm{IOO}$. Now Depositor IB banks at Bank B and deposits the check for $\$$ I Oo in Bank B, and Depositor $2 A$ banks a Bank A and deposits the check for \$Ioo in Bank A. In the clearings, Bank A will owe Bank B \$Ioo, and Bank B will owe Bank $A$ A Ioo, and thus the two payments will cancel out and settlement requires no payment. In this way, the banks can increase their loans without a change in their 
reserve position. The leadership of the New York Clearing House developed this strategy during the panic of I857, shortly after its founding in I 853 (Myers I93 I).

But if the check payments are distributed asymmetrically across the banks, some banks obtain debtor positions in the clearings. Now imagine that instead Borrower I wrote a $\$$ I Oo check to Depositor I A who banks at Bank A. Bank A can just increase Depositor I A's account by \$IOO and decrease Borrower I's account by \$IOO without any other changes. Thus, at the clearing, there is only one check, written by Borrower 2 which is deposited by Depositor $2 \mathrm{~A}$ at bank A. Therefore, Bank B owes Bank A $\$$ IOO in the clearings and will suffer a reserve outflow at settlement. In general, if spending of the borrowed funds is distributed asymmetrically at certain institutions, these institutions would obtain a creditor position in the clearings, so other institutions must have a debtor position and will suffer reserve outflows. If banks anticipated suffering reserve losses in the event that spending was concentrated at other banks, a bank might not want to expand loans, thus limiting credit during panic periods when it was needed most by the business and financial community.

As an example, New York City banks varied in their responses to the panic of I 893 . We can compute the percentage change in total loans (where total loans = loans + US bonds on hand + US bonds to secure deposits + other stock, bonds and mortgages) from December I 892 to September/October I 893 using reports to national and state regulators. Of the 64 clearinghouse member banks, I I banks increased loans by an average of 6.7 percent, rising form a total of $\$ 79.72$ million to $\$ 85.05$ million. The remaining 53 banks contracted lending by an average of I 3.2 percent, falling from a total $\$ 36$ I.6 million to $\$ 309.8$ million. See Hoag (20 I 2 ) for more information about the data.

In times of financial crisis, the associated member banks would meet and resolve to allow the issue of loan certificates (Cannon 1908). In New York, interested member banks obtained the loan certificates from a special committee of bank officers, the Loan Committee. Banks deposited collateral subject to a haircut, usually at least 25 percent. In the unlikely event that the bank failed and excess collateral was not enough to pay off the loan certificate, the loan certificate was backed by a joint pledge of redemption of the entire clearinghouse membership. Banks with a debit balance at the clearing could pay the creditor banks in the settlement with loan certificates instead of with specie or currency. After the settlement took place, the creditor bank would hold the loan certificate and earn interest at a specified rate (usually 6 or 7 percent). (Occasionally in New York, clearinghouses required a commission of one quarter of I percent per 30 days (Cannon I908, p. 98) to pay for the expenses of printing the loan certificates and compensating workers for overtime, but the commission was not necessarily common to all crises.) The creditor bank could also submit the loan certificate in place of cash if the creditor bank became a debtor bank in a future clearing. Banks that borrowed loan certificates 
eventually redeemed them, releasing the collateral pledged to the Loan Committee. The central clearinghouse would administer interest payments, periodically collecting interest due from borrowing banks and disbursing it to banks based on their holdings of loan certificates over the last period.

Loan certificates were subject to some restrictions. First, nonmember banks were not eligible to borrow clearinghouse loan certificates. Second, in earlier periods, loan certificates could only be used to satisfy debts incurred from the clearing mechanism at the clearinghouse. Beginning in I 893, some clearinghouses in smaller cities in the South did allow clearinghouse loan certificates to circulate in the hands of the public, a version that we might call clearinghouse currency certificates, to distinguish them from clearinghouse certificates and clearinghouse loan certificates (Andrew I908; Gatch 2013). (Cannon (I908, p. I20) observes that, of course, clearinghouse currency certificates also circulated among the public in cities without a clearinghouse.) Timberlake (I984) notes that the loan certificates of all types were probably illegal or at least taxable. For this article, we focus on the main service of clearinghouse loan certificates within the clearinghouse. In particular, the New York Clearing House did not allow member banks to employ the loan certificates for activities other than settlement of balances obtained through clearing. According to the New York Times (20 September I 893), New York Clearing House members would be fined '\$IOo for each offence' and could face the loss of clearinghouse membership.

Clearinghouse loan certificates allowed the banks to expand loans with asymmetric spending patterns. In the situation above with asymmetric payments resulting in a settlement balance of $\$ 200$ from Bank B to Bank A, Bank B could tender loan certificates in the settlement rather than reserves. Bank B could obtain loan certificates on collateral and give the loan certificates to Bank A in temporary settlement of its debt at the clearinghouse. The loan certificates would thereby facilitate the expansion of loans during crises, as the banks could expand loans without fearing their reserves would decline. When New York banks made loans to brokers who purchased securities and thereby supported stock market prices, the banks purchased a public good (Tallman and Moen 2003). The loan certificates allowed the banks to contribute to higher stock prices during crises by shifting some of the risk to other member banks who chose not to lend to stock market operators. Alternately, Tallman and Moen (2OI2) argue that the loan certificates could finance gold imports. While it seems odd that competing banks might cooperate, Phillips (2003) suggests that banks might be willing to lend loan certificates to their rivals to prevent contagion.

Clearinghouse loan certificates probably did not count as official bank reserves. Timberlake describes clearinghouse loan certificates as 'equivalent to bank reserves, that is, high-powered money' (I984, p. 8). While it is true that clearinghouse loan certificates could be used in place of physical funds in settlement of debts at the clearings, loan certificates did not fulfill the reserve requirement. According to sections 3 I and 32 the National Bank Act of I 864, reserves could only consist of lawful money or, for banks outside New York, deposits on a specific urban bank. Clearinghouse certificates, representing lawful money, were permitted to count as reserves, while 
clearinghouse loan certificates, which were backed by security collateral, presumably would not. Timberlake (I984, p. Io) views the Comptroller of the Currency in 1907 as admitting that clearinghouse loan certificates were considered reserves, when most likely the Comptroller was referring to certificates 'representing specie or lawful money deposited for the purpose' as reserves (Office of the Comptroller of the Currency I907, p. 64), that is clearinghouse certificates and not clearinghouse loan certificates.

\section{IV}

With this background in clearinghouse operations, we can develop our own hypotheses about the evaluation of clearinghouse loan certificates. This article suggests that clearinghouse loan certificates bear some similarities to interbank loans. In particular, clearinghouse loan certificates replicate the cash flows of interbank loans. When a bank submits a loan certificate in the clearings in place of currency, another bank experiences a delay in obtaining a payment of currency that ordinarily would have occurred. That is, one bank would have obtained in the settlement a payment in gold or currency but instead gets a loan certificate that pays interest to the holder. Following our original example of clearing above, imagine that Bank B owes Bank A $\$ 200$ at settlement after net clearing. Bank B goes to the Loan Committee, submits at least $\$ 267$ in collateral, and receives a loan certificate with a face value of \$200. Instead of Bank B giving Bank A \$200 in cash, Bank B presents the clearinghouse manager with a loan certificate for $\$ 200$ at the daily settlement, and the manager distributes the loan certificate to Bank A. What has happened in this transaction? Bank A has essentially loaned Bank B the $\$ 200$ in cash: Bank A was going to get a payment of $\$ 200$ now, but instead Bank A accepted the loan certificate. Bank A holds the loan certificate instead and collects interest on its $\$ 200$. Thus, clearinghouse loan certificates permit a delay in the payment of reserves for debts incurred at the clearinghouse.

Contemporary journalists described the loan certificates as interbank loans and emphasize that individual banks holding the loan certificates actually made loans. A New York Times editorial describes the operation of loan certificates (20 September I 893):

When they [New York Clearing House loan certificates] are received by a creditor bank they are entered up as a loan precisely as any other loan would be entered up ... In short, a New York Clearing House loan certificate is a medium for borrowing money between the banks for use in an emergency, and is the simplest way for permitting a heavy reduction of deposits without compelling the banks who lose deposits sharply to contract their loans, and thus injure their customers at a time of panic... The banks holding outstanding certificates pay 6 percent interest thereon, but they receive 6 percent interest on the average amount that they hold daily, so that in many cases the receipts of interest offset the payments. 
Here, the editorial author notes that the banks document loan certificates as interbank loans. In particular, the lending bank records a loan on its own balance sheet when receiving a loan certificate in the daily settlement. Further, the editorial claims that individual banks use the same accounting for clearinghouse loan certificates as they did for ordinary loans. (However, the editorial author makes the accounting appear more simple than it was, for at least some banks in I893 did not account for holding the loan certificates by simply adding them to loans.)

But the loan certificates could be used in subsequent clearings, and that means the lender of the loan certificate could change. Suppose in the clearing the next day Bank $\mathrm{A}$ is a debtor at the clearinghouse and decides to submit Bank B's loan certificate in place of reserves. Imagine that Bank $\mathrm{C}$ is a creditor and receives Bank B's loan certificate in the clearing in place of reserves. Now instead of Bank A receiving interest on the loan certificate, Bank $\mathrm{C}$ will receive the interest on the loan certificate. Thus, Bank B has now borrowed money from Bank C. Bank A transferred its claim on future reserves to Bank $\mathrm{C}$ by tendering them to Bank $\mathrm{C}$ in place of cash during the daily settlements.

Loan certificates must be allocated across the creditor banks in the daily settlement. To settle balances, the debtor banks could pay with a mix of reserves and loan certificates. Thus, the settlement must determine which banks obtain loan certificates and which banks obtain cash. Cannon (I908, p. 85) states that early loan certificate regulations required that each creditor bank obtain an equal proportion of its settlement in loan certificates ('and they shall be received by creditor banks during that period, daily, in the same proportion as they bear to the aggregate amount of the debtor balances paid at the clearing-house'). One might speculate that the manager exercised discretion over which banks received loan certificates in the settlement or that the manager consulted the banks about which banks were willing to receive loan certificates instead of reserves. At the height of financial crises, nearly all debts at the clearinghouse were settled with loan certificates and not with reserves (Sprague i9io).

Although the similarities between loan certificates and interbank loans can prove valuable, we should also observe several differences between loan certificates and interbank loans. Unlike interbank loans, the interest rate was fixed at the rate for all loan certificates during a given panic, usually 6 or 7 percent. Whereas interbank loans could be negotiated secretly between individual banks, clearinghouse leadership recorded which banks borrowed loan certificates. Further, interbank lenders could refuse to make loan transactions, whereas creditor banks that were members of the clearinghouse would need to accept the loan certificates when they might have preferred to receive cash in settlement. However, viewing the loan certificates as replicating the cash flows of interbank loans helps us to understand the operation of the loan certificates, even if the loan certificates differ in several respects from actual interbank loans.

Once the panic had passed, banks faced the task of redeeming their loan certificates. The process of the redemption of loan certificates is not as well documented. After a crisis began to wane, suppose a bank that borrowed loan certificates desired to reclaim 
its collateral security. Banks were paying 6 or 7 percent interest, and they might not be able to obtain such a high rate on alternate investments such as call loans once the panic began to subside. Banks that borrowed loan certificates needed to obtain the specific loan certificate issued by that bank. Apparently, it was not enough to produce any loan certificate, a bank had to redeem its own specific loan certificate that it had issued. At most clearinghouses, the name of the borrowing bank was written in ink on the loan certificate. A brief summary of the redemption procedure was written on a loan certificate in I 873 (Cannon, I908, p. 89):

On the surrender of this Certificate by the depositing Bank above named, the Committee will endorse the amount as payment on the obligation of said Bank, held by them, and surrender a proportionate share of the collateral securities held therefore.

According to the loan certificate, the bank must procure its own certificates and then bring those certificates to the Loan Committee, which would cancel the loan certificates and release an appropriate amount of collateral.

Thus, redemption required obtaining the bank's own loan certificate, which was presumably in the hands of another bank. Of course, the borrowing bank would not necessarily know which other bank held its loan certificates. Because the loan certificates bore relatively high rates of interest relative to the market once the panic had begun to subside, banks that held loan certificates would need some incentive to relinquish the loan certificates of another bank. To encourage redemption, banks would occasionally announce to the membership that their loan certificates would cease bearing interest on a given date. In I884, the Loan Committee alerted the members that a bank declared that its loan certificates would cease to bear interest. A bank might seek to redeem only a portion of its outstanding loan certificates, as banks would refer to specific loan certificates by series number and denomination. How the bank obtained its own loan certificate remains conjecture. The borrowing bank could recover the loan certificate through the settlement. The bank holding the loan certificate could submit the loan certificate in settlement of its balance on the next day that it was a debtor bank in the clearings, but this action might take a few days until it was a debtor. Further, it would require the borrowing bank to be a creditor on the same day. Perhaps the clearinghouse manager would manually remove loan certificates submitted during the settlement and allow the borrowing bank to purchase them at face value. Alternately, perhaps if the clearing balances were unfavorable, the borrowing bank could transact directly with the lending bank and pay the face value of the loan certificate to the holding bank in exchange for the loan certificate, although this transaction remains merely conjecture. Perhaps the most natural and most likely method of redemption would involve passing the loan certificates through the clearings like checks: the clearinghouse could treat the loan certificate as a check on the bank borrowing the loan certificate. Once interest ceased, the bank holding the loan certificate could submit the loan certificate through the clearing mechanism, which would result in a credit for the bank holding the certificate (hence the return of the funds borrowed), a debit for the 
borrowing bank, and the borrowing bank obtaining possession of the loan certificate with its other checks. The lack of clarity about the redemption of loan certificates is unfortunate, because a description of the redemption process could help to resolve the standing of loan certificates as interbank loans or loans from the central clearinghouse. In particular, if loan certificates are interbank loans, the lending bank would require some cash inflow, whether indirectly as an additional credit in the settlement or directly in a side payment, to compensate for relinquishing the loan certificate.

Viewing loan certificates as interbank loans increases the importance of tracking which banks held the loan certificates. Every borrower has a lender. And in this case, based upon the discussion above, the lender was not the clearinghouse but was the individual bank that held the loan certificates. Each individual loan certificate was held by some individual bank, and that individual bank ultimately earned the interest on the loan certificates. A bank could hold loan certificates through two methods. First, a bank could receive certificates through the clearings on days when they were a creditor. Second, sometimes the banks could borrow loan certificates and then decide to hold their own certificates and not submit them into the clearings. In this case, the bank pays interest for borrowing the loan certificate, but it receives the same amount of interest for holding the loan certificate. On net, the bank pays no interest, and we could characterize this behavior as the bank lending to itself.

It is not clear why banks would hold loan certificates but not use them. Banks occasionally expressed an interest in holding loan certificates as a precaution: the bank did not actually need the certificates, but it borrowed some just in case. The precautionary motive does not seem to be relevant. During panic periods, the Loan Committee met every day after the exchanges and before the settlement, so banks could choose their level of borrowing based on their settlement balance for that day. Later during the course of the panic, the Loan Committee would decrease the frequency of its meetings to two or three times per week. However, the Loan Committee would typically only meet less frequently once it was clear that individual banks were no longer interested in borrowing loan certificates and simply met to oversee the redemption of loan certificates. So accumulating the borrowing of loan certificates held no option value since loan certificates were available every day during panic periods at the convenience of the banks.

A second possibility that might explain borrowing loan certificates without using them might be an aggregate ceiling on borrowing. Especially in early panics, the New York Clearing House would set an aggregate limit of an issue of loan certificates. In I 873 , some banks expressed fear that they would not get their share of loan certificates and borrowed to ensure they had their share. However, in I 873 the associated banks of New York raised the aggregate limit of loan certificates, and the aggregate ceiling never appeared to bind in that panic or in any subsequent panic, so banks should be relatively free of this concern (Myers I93 I), especially in later panics.

A final motive might be to lessen the stigma of borrowing. While there are many versions of stigma, one example might be when weaker banks might fear that 
borrowing loan certificates would disclose bank weakness to market participants. If more or preferably all banks borrow loan certificates, then market participants would not be able to make inferences about the solvency position of individual member banks based on the borrowing from a lender of last resort. Hoag (2012, 20I5) does not observe that weaker banks are more reluctant to borrow loan certificates, as member banks with lower capital/asset ratios were not less likely to borrow loan certificates or to borrow lesser amounts of them. Of course, other types of stigma might persist.

The lending behavior of individual member banks of the clearinghouse has important implications for viewing clearinghouse loan certificates as a lender of last resort. Suppose we were interested in which banks borrow from a lender of last resort. In the case of loan certificates, banks that borrow loan certificates could also be lenders of loan certificates. In particular, a bank that borrows loan certificates might actually lend more money than it borrowed, thus being a net lender rather than a net borrower. In I 884 and I 893 , about a quarter of the banks that borrowed loan certificates were actually net lenders (Hoag 20I5). Therefore, we should avoid studying only those banks that borrowed loan certificates, and we should take the lending of loan certificates into account. For the same reasons, macroeconomic investigations should hesitate to focus on the total amount borrowed, because again banks could hold a substantial amount of their own certificates without submitting them in the daily settlement.

\section{$\mathrm{V}$}

Now that we have compared clearinghouse loan certificates to interbank loans, we can contrast this interpretation to previous descriptions of loan certificate issue. The literature suggests several possible levels of clearinghouse involvement with loan certificates, ranging from most centralized to least centralized. First, during times of financial stress the clearinghouse members would merge into a single large bank (a 'superbank' or the resulting merged bank) and become a single financial institution. Second, the banks could remain distinct individual banks but the central clearinghouse organization could act as a lender of last resort on its own account and make loans directly to individual banks. Third, while the clearinghouse might not loan on its own account, it could guarantee loan certificates, and by doing so the clearinghouse could stand between the banks that borrowed loan certificates and the bank that lent certificates, much like a futures clearing house. Finally, the associated banks simply guaranteed the loan certificates after the collateral and the solvency of the individual bank was exhausted. While all of the descriptions have some merit, the last description fits the historical record the best.

First, some authors believe that the individual clearinghouse member banks would merge into a single large bank during panic periods. For example, Gorton (I985, p. 280) states that: 
When a panic occurred, the structure of the banking industry was radically altered by the metamorphosis of the clearinghouse into a single, firm-like organization uniting the member bank in a hierarchical structure topped by the Clearinghouse Committee.

As explanation for the change in organizational structure, Gorton cites the issue of clearinghouse loan certificates. Similarly, Gorton and Tallman (20 I 4, p. I 5) state that:

Because the clearinghouse loan certificates were liabilities of the membership jointly their issuance signaled that the clearing members were binding themselves in to a single institution. This was a remarkable process, of turning individual privately-owned banks into a single large bank.

These authors again assert that the clearinghouse transformed itself from many banks into one giant superbank during panic periods.

Clearinghouses did obtain unusual authority during crises, which varied across panic and city. For example, one source claims that the Clearing House Committee exerted control over all loans made by both members and nonmembers who cleared through member institutions in the panic of 1907 in New York (Commercial and Financial Chronicle, 2 November I907, p. II I I). There does not appear to be an explicit mandate from the members to grant these powers to the Clearing House Committee. How committee members enforced these provisions, if actually enacted, does not appear to be specified. However, the first hypothesis not only asserts that financial decisions were coordinated by the individual banks; it claims that the financial structure of the banks was altered so that the banks became a single firm.

The description of clearinghouse member banks exhibiting a higher level of bank cooperation draws inspiration from the historical record. The New York Clearing House increased cooperation during the panic of 1873 by accumulating reserves in a common fund directed by clearinghouse officers (Sprague I9I0). While the historical record makes it clear that the banks allowed their reserves to be deployed according to strategic decisions made by New York Clearing House leadership, it is less obvious that all liabilities of each member bank were jointly guaranteed by the member banks. Forming a single firm means that the banks jointly insured the liabilities of all member banks: the superbank coalition failed if and only if all of the individual banks failed. The banks could agree to pool their reserves, but that need not imply a mutual guarantee of all liabilities of each individual bank. If only reserves were pooled, individual banks in the coalition could still suffer asset shocks that would result in the failure of an individual bank but not necessarily the entire coalition. Moreover, a mutual guarantee applied to the loan certificates would not necessarily indicate that all liabilities of member banks would be mutually guaranteed. Loan certificates only formed a portion of the portfolio of member banks, so a mutual guarantee limited to the loan certificates would not necessarily form a very large fraction of the portfolio of the remaining member banks.

Higher levels of cooperation only existed for limited periods and perhaps only in New York. The associated banks of New York also used their reserves for 'mutual 
aid and protection' in I860 (Swanson I908), when reserves were reallocated among the banks by administrative action. Again in this case, we have no direct evidence of a mutual guarantee of all liabilities. However, while the banks cooperated in I873 in New York, the reserve pooling experiment was not repeated in subsequent years. Sprague (I9IO) and Wicker (2000) explain why the banks in New York did not continue the reserve pooling agreement in panics after I873. Sprague (I9Io, pp. I2O-I) argues that the principal-agent problem (inequities in reserve pooling when banks accepted special deposits not subject to joint oversight) and the moral hazard problem (safer banks felt they subsidized riskier banks who took more risk before crises and then expected infusions of reserves from safer banks during crises) prevented reserve pooling in later crises. Hoag (2012) evaluates the moral hazard hypothesis for the next full crisis, which occurred in I893. After I873, each bank deployed its reserves according to its own preferences. In addition, outside of New York City we have no direct evidence that banks in other cities either pooled their reserves or established mutual guarantees of liabilities other than loan certificates. Swanson (I908) states that Boston did not follow the example of New York in pooling its reserves in I 860. While information about other clearinghouses is less comprehensive, Cannon (I908) does not record any instances where clearinghouse banks in other cities merged into a superbank during panics. Thus, during most panics of the National Bank Era (1863-I9I3) including all panics after I873, the New York banks did not pool their reserves. Without evidence of any instances when banks temporarily merged and mutually guaranteed all liabilities, the first and broadest hypothesis does not appear to describe most clearinghouse behavior.

Second, some authors consider the central clearinghouse organization itself as an actual lender of last resort. In fact, contemporary observers frequently spoke of the New York Clearing House Association as lending to individual banks. For example, James G. Cannon, author of the book Clearing Houses (I908), states that:

The [loan] certificates were essentially temporary loans made by the banks banded together as a clearing-house association to the members of such association, and were available to such banks only for the purpose of settling balances due from and to each other. In the words of the Comptroller of the Currency, they were but due bills, and their sole function consisted in discharging the single obligation at the clearing-house. (p. I25)

While Cannon describes loan certificates as temporary loans, he seems to attribute the lending to member banks by the Associated banks jointly, that is to the clearinghouse itself. In support of this claim, recall that the loan certificate was considered an 'obligation' to the Loan Committee. Cannon held important positions, including membership on the New York Clearing House Loan Committee of 1907 (New York Times, 27 October 1907), so we must hesitate to contradict his close participation in historical events.

The description of clearinghouse organizations lending directly to individual member banks does not describe the lending portion of the operation of the loan certificates. To evaluate the claim, we must consider the cash flows of the loan 
certificates. The cash flows show that the central clearinghouse did not make loans. In particular, the central clearinghouse did not retain the interest from the loan certificates. A lender must obtain the interest on the loan. For example, the Federal Reserve collects interest on discount window lending. Borrowing loan certificates was not free, as the interest rate was invariably 6 or 7 percent. Where did the interest on the loan certificates accumulate? In the case of loan certificates, the interest was not retained by the central clearinghouse, instead it was delivered to other member banks, the banks that held the loan certificates. Clearinghouses kept records of the interest owed by the banks borrowing loan certificates and the amount owed to banks that held the loan certificates (Cannon I908). The interest was paid out periodically to banks that held the loan certificates; the interest was not retained by clearinghouse officers for use by the central organization. Since the clearinghouse itself did not accumulate interest on the loan, it was not a lender by itself alone. In order for the clearinghouse to lend, the borrowing bank obtained the participation of an individual member bank which lent reserves.

It is possible to interpret a clearinghouse organization as a lender, but that view requires a shadow transaction. Imagine that the clearinghouse lent loan certificates to a borrowing bank. Once the bank submits the loan certificate in the settlement at the clearinghouse, it is as though the clearinghouse gave the bank additional reserves, the reserves the bank would have had to pay if it had not tendered the loan certificate. But where does the clearinghouse itself obtain reserves? The clearinghouse has no supply of cash on hand. Effectively, the clearinghouse obtains the reserves by borrowing from the banks that hold the loan certificates. When banks received the loan certificates, they would forgo a payment in reserves from the debtor banks. Because it had no funds of its own, the clearinghouse would borrow funds from the individual lending banks and advance those funds to the borrowing bank in the settlement. The clearinghouse borrowed these funds from its member banks at the same rate as it lent. That is, the clearinghouse is a lender, but each time it lends to an individual member bank it requires a loan from some other individual member bank. Imagining the clearinghouse as an intermediary leads to the third hypothesis.

Third, we can consider the hypothesis that the clearinghouse stood between the banks. Tallman and Moen (20I2) suggest that by guaranteeing the loan certificates, a clearinghouse intermediates the transaction between the borrowing bank and the lending bank: 'in a sense, the New York Clearing House itself was the counter party to the holders of clearing house loan certificates' (p. 28I). Now we know that the clearinghouse did administer payments and distribute interest across the member banks. But the third hypothesis requires a stronger relation between the clearinghouse organization and the individual banks; it requires that the clearinghouse organization acted as an intermediary and guaranteed timely payments associated with the loan certificates between borrower and lender. While the evidence for this claim is not necessarily conclusive, to a first approximation the clearinghouse does not appear 
to be insuring the prompt payment of all cash flows associated with the loan certificates.

Intermediation by a clearinghouse was not its ordinary practice. Unlike futures clearinghouses, Edwards (I984) notes that modern bank clearinghouses do not intermediate transactions. The I 888 version of the Constitution of the New York Clearing House Association states in section 2 that the 'responsibility of the Association is strictly limited to the faithful distribution by the Manager among the creditor Banks, for the time being, of the sums actually received by him' (Squire I888, p. 39). That is, this particular clearinghouse association as a separate organization had no liability to insure the payment of settlement balances. Cannon (I908, p. 37) emphasizes that the clearinghouse was just an 'agent' for distributing settlement payments and was not responsible for insuring the payments. Several court cases (Crane $v$. Fourth Street National Bank (I 896), Yardley v. Philler (I 897)) outlined how a clearinghouse was merely an agent that collected the checks, so banks still owned the checks they submitted and the clearinghouse did not act as a central counterparty (Bryan I9I 5). But the case of loan certificates might be different from general clearing procedures due to the explicit mutual guarantee on the loan certificates by all member banks. In particular, the clearinghouse itself held a lien on the collateral for the loan certificates (Philler v. Patterson (I 895)).

Compare the lending of clearinghouse loan certificates to trading in a futures clearinghouse. In a futures clearinghouse, the clearinghouse stands between the buyer and seller of the futures contract, at least for net transactions (Bernanke I990). That is, the clearinghouse acts as a central counterparty, serving as the buyer to every seller and the seller to each buyer. In the event that a counterparty fails, the clearinghouse fulfills the contract at expiration. In the meantime, the clearinghouse continues to mark the contract to market and continues to make payments to the surviving counterparty in the event that the futures price continues to move against the defaulting counterparty. The futures clearinghouse itself would then become a creditor of the defaulting counterparty if margin requirements or performance bonds did not sufficiently cover the costs. One could argue that the joint guarantee of loan certificates by all member banks effectively places the bank clearinghouse organization between the bank borrowing loan certificates and the bank lending the loan certificates. Thus, if bank clearinghouse behavior paralleled a futures clearinghouse in the case of loan certificates, in the event of a default of loan certificates the bank clearinghouse should pay off the loan in cash to the bank holding the loan certificate. Of course, for a bank clearinghouse that guarantee only requires an inflow of funds in the case that the collateral for the loan certificates of the defaulting bank and the receiver of the bank cannot generate enough revenue to cover the loss. In order to make up the difference, the clearinghouse will have to take the loss out of its own capital or requisition the clearing members for enough funds to make up the losses to the counterparty of the defaulting institution.

Most bank clearinghouses would meet a default on loan certificates through requisition rather than through its own resources. The clearinghouse as a distinct 
organization from the individual member bank had very few assets. Bank clearinghouses were organized as voluntary organizations and had no capital of their own. The New York Clearing House typically set annual membership dues on the member banks to balance the budget, avoiding the accumulation of assets. A few clearinghouses, such as Philadelphia, required deposits of securities to protect against adverse clearing balances, but these were limited generally to a fraction of book capital, and many clearinghouses did not require such security provisions (Cannon I908, p. 219). Further, the clearinghouse organization had little access to liquid funds of its own. Cash raised during the settlement process was immediately paid out to creditor banks. The only resource in the possession of the Loan Committee was the collateral on the loan certificates. Paying the holders of defaulted loan certificates would require selling the collateral backing the loan certificates or seeking a rapid cash infusion from surviving member banks.

Thus, if bank clearinghouses acted as intermediaries in the same way that futures clearinghouses did, we might expect bank clearinghouses to sell the collateral and immediately pay off member banks holding loan certificates shortly after the failure of the borrowing bank. However, the resolution of failures on loan certificates might be somewhat different than the resolution of failures of futures contracts because futures contracts have an expiration date. Loan certificates did not necessarily have a specific expiration date. (According to Cannon (I908, p. 85), the New York Clearing House did initially specify a 30-day maturity in 1860 , but the panic period in that year and in subsequent crises lasted longer than 30 days, and we observe no evidence of rolling over loan certificates in later crises, so the due date was probably ignored. An initial due date of I November was originally established in late September I 873, but the duration of the crisis eventually required rescinding the maturity of the loan certificates. The relatively high rate of interest paid on loan certificates encouraged the banks to redeem any outstanding certificates as soon as interest rates fell to pre-panic levels.) But at some point, counterparties would expect the central clearinghouse to intervene and return funds to the lending banks. Otherwise, the funds of the banks would be locked up in the loan certificates, and lending banks would not have free use of their funds until the bank failure was resolved.

As a test of the theory, we can investigate the behavior of the New York Clearing House upon the failure of the Metropolitan National Bank in I884. The Metropolitan National Bank experienced difficulty due to its connections with speculators on railroad securities (Wicker 2000, p. 36). Examiners from the New York Clearing House and the national bank examiner agreed that the Metropolitan was solvent (Commercial and Financial Chronicle, i884, p. 535). In an effort to keep the Metropolitan from failing, the Metropolitan National Bank borrowed more than $\$ 7$ million in loan certificates, more a quarter of the outstanding amount in I 884 (Wicker 2000, p. 37). Cannon (I908, p. 97) states that all loan certificates were redeemed before October I 884 . However, the course of events suggests otherwise, as the Commercial and Financial Chronicle states that more than \$5 million of loan 
certificates remained outstanding as of 3 October I884 (6 December I 884, p. 635). Based on information received from the manager of the New York Clearing House, loan certificates that were issued to the Metropolitan Bank were not redeemed until 23 September I 886 (Office of the Comptroller of the Currency I907, p. 66). But the Metropolitan failed in November I 884, which was before the loan certificates were redeemed.

The resolution of the failure of the Metropolitan bank that failed in I 884 after having borrowed clearinghouse loan certificates suggests that the New York Clearing House did not act as a central counterparty. The clearinghouse does not appear to pay off the lending banks when a borrowing bank fails. Reimbursing lending banks would have required a special requisition on the members because the amount borrowed was so large relative to the assets on hand of the central clearinghouse. To the best of my knowledge, the Minutes of Clearing House Committee of the New York Clearing House Association contain no record of a special requisition on the member banks to pay cash to the holders of the loan certificates of the Metropolitan. Nor is there any reference to a special requisition in I884 through I 887 when the banks set the budget for the year (Minutes of the Clearing House Committee, I 884-7). Matters at this level of importance such as a special requisition usually initiated discussion by the membership. Thus, while it is possible that such records did not survive, we do not see evidence that the New York Clearing House, as an institution, stood between the banks holding the loan certificates and the failed Metropolitan bank.

Ordinarily, we might expect a central clearinghouse to sell off the collateral and immediately reimburse counterparties to failed bank. Instead, the New York Clearing House Association held collateral for more than a year in the hope that the price would rise after the crisis. At least a quarter of the collateral securities consisted of a block of illiquid bonds of the East Tennessee, Virginia and Georgia Railroad. The Loan Committee did not immediately sell the bonds and waited until at least September I885 for the securities to increase in price (New York Times, 5 September I885). While the fact that the central clearinghouse sold the bonds in a block appears to support the theory of clearinghouse as a central counterparty, the amount was too large for the clearinghouse itself alone to have reimbursed the individual banks without a requisition of funds. Almost a year later, the central clearinghouse had not reimbursed the individual banks, and the individual banks were still party to the loan certificate transaction. The banks suffered the liquidity risk without having received the return of their funds on the failure of the Metropolitan in November I 884 .

Furthermore, if the clearinghouse stood between trades in a way similar to a futures clearinghouse, the clearinghouse should have made the interest payments to the lending banks. Futures clearinghouses continue to make market payments to firms whose counterparty has failed: the firm gets the full value of the trade even if its counterparty defaults. At an interest rate of 6 percent and loan certificates of $\$ 5$ million outstanding, the bank would need to pay $\$ 300,000$ in interest annually. This sum was 
large enough to require a requisition on the banks, as the annual interest payment exceeded the annual expenses of the New York Clearing House during this period (Minutes of the Clearing House Committee, I 884-7). Again, we see no evidence of a requisition on the members in the few years after i 884 . While we have no contemporary testimony regarding the disposition of the loan certificates, we hazard the educated hypothesis that the New York Clearing House, as an institution, was not making the interest payments to the individual banks that held the loan certificates: these banks bore the liquidity cost of not having access to the funds tied up in the loan certificates. Because the New York Clearing House neither generated interest payments on schedule nor immediately relieved member banks of their investment in the principal of nonperforming loan certificates, it seems likely that the central clearinghouse organization was not intermediating payments among the member banks.

After discarding the three previous alternatives, we are left with the fourth and weakest alternative, namely that the associated members merely guarantee the final payment of the loan certificates after collateral and the credit of the borrowing bank have been exhausted. The members do not guarantee the timeliness of the intermediate payments such as interest or even the prompt repayment of principal in the case of bank failure. Although the members jointly guarantee the eventual repayment of the loan certificates (though not necessarily immediately on failure a participating institution), the actual loan of reserves comes originally from a member bank that should have received reserves in the settlement and not from the clearinghouse organization itself.

\section{I}

This article explores the mechanics of clearinghouse loan certificates as practiced by the most historic large clearinghouses during the majority of financial crises of the late nineteenth and early twentieth centuries. In particular, we focus on the structure of loan certificates issued through the New York Clearing House. Through a more detailed examination of loan certificate operations, we observe that the loan certificates bear some resemblance to interbank loans. This description limits the financial obligations of the central clearinghouse. First, while the role of the clearinghouse in coordinating the cooperative reserve agreement is well documented during the crisis of 1873 in New York, we have no evidence that clearinghouses guaranteed the liabilities of member banks beyond the mutual guarantee of the loan certificates. Second, clearinghouses themselves did not make loans to individual banks that borrowed loan certificates because clearinghouses did not retain the interest on such loans. Finally, clearinghouses did not appear to serve as the central counterparties to the cash flows associated with the loan certificates because they did not immediately reimburse the liability associated with the loan certificates of failed institutions.

Despite the structure of the transactions, one should not underplay the contribution of the central clearinghouse to the capacity to operate as a lender of last resort. 
The central clearinghouse made the interbank loans possible through the clearing system, thereby serving as an emergency lending facility. Rather than negotiating interbank loans individually, member banks could simply make loans to their customers and then borrow clearinghouse loan certificates when the banks experienced a debtor position in the clearings. In contrast, an attempt by an individual bank to obtain financing on its own during a crisis would have sent a strong signal to the market that the bank faced financial difficulties. Most likely, the asymmetric information problem would have made borrowing problematic if not impossible for individual banks. The central clearinghouse decreased the costs of administrating a system of interbank borrowing to the point where borrowing was easily feasible. The daily clearings gave banks many opportunities to employ the borrowed loan certificates. In this way, the clearinghouse structure was an important ingredient to the ability of the associated banks to fight financial crises.

Submitted: 28 July 2016

Revised version submitted: 20 October 2016

Accepted: 28 October 2016

First published online: 28 December 2016

\section{Sources}

Commercial and Financial Chronicle, I884.

New York Clearing House Association, Minutes of the Clearing House Committee, vols. 3 and 4 (New York).

New York Times, I 884-I907.

\section{References}

ANDREW, A. P. (1908). Substitutes for cash in the panic of I907. Quarterly Journal of Economics, 22, pp. 497-5I6.

BERNANKE, B. (I990). Clearing and settlement during the crash. Review of Financial Studies, 3, pp. I33-5I.

BRYAN, G. (I9I 5). The law of clearing houses. Virginia Law Review, 2, pp. 447-56.

CANNON, J. G. (I908). Clearing-houses. New York: D. Appleton and Company.

Crane v. Fourth Street National Bank I73 Pa 566 (I896).

DUNBAR, C. (I929). The Theory and History of Banking, sth edn. New York: Putnam.

EDWARDS, F. (I984). The clearinghouse association in futures markets: guarantor and regulator. In R. Anderson (ed.), The Industrial Organization of Futures Markets. Lexington, MA: Lexington Books.

GATCH, L. (2013). The clearinghouse certificate as a cash substitute, I857-I933. In N. Shafer, T. Sheehan and F. Reed (eds.), Panic Scrip of 1893, 1907 and 1914: An Illustrated Catalog of Emergency Monetary Issues. Jefferson, NC: McFarland.

GORTON, G. (I985). Clearinghouses and the origin of central banking in the United States. Journal of Economic History, 45, pp. 277-83.

GORTON, G. and MULLINEAUX, D. (I987). The joint production of confidence: endogenous regulation and nineteenth century commercial-bank clearinghouses. Journal of Money, Credit, and Banking, I9, pp. 457-68.

GORTON, G. and TALLMAN, E. (20I4). How do banking panics end? Working paper.

HOAG, C. (2OII). Clearinghouse membership and deposit contraction during the panic of I893. Cliometrica, 5, pp. I 87-203. 
HOAG, C. (20I2). Clearinghouse loan certificates during the Panic of I893. Academy of Banking Studies Journal, II, pp. 93-I05.

HOAG, C. (2015). Clearinghouse loan certificates as a lender of last resort. Trinity College Working Paper I $5-03$.

JAMES, J. and WEIMAN, D. (2005). Financial clearing systems. In R. Nelson (ed.), The Limits of Market Organization. New York: Russell Sage Foundation.

JAMES, J. and WEIMAN, D. (20I0). From drafts to checks: the evolution of correspondent banking networks and the formation of the modern US payment system, I850-I9I4. Journal of Money, Credit, and Banking, 42, pp. 237-65.

JAREMSKI, M. (20I5). Clearinghouses as credit regulators before the Fed? Journal of Financial Stability, I7, pp. IO-2I.

MOEN, J. and TALLMAN, E. (2000). Clearinghouse membership and deposit contraction during the panic of I907. Journal of Economic History, 60, pp. I45-63.

MOEN, J. and TALLMAN, E. (2003). The call loan market in the United States prior to the Federal Reserve system. Federal Reserve Bank of Atlanta Working Paper 2003-43.

MOEN, J. and TALLMAN, E. (2OI 3). Close but not a central bank: the New York Clearing House and issues of clearing house loan certificates. Federal Reserve Bank of Cleveland Working Paper I 3-08.

MYERS, M. (I93 I). The New York Money Market. New York: AMS Press.

OFFICE OF THE COMPTROLLER OF THE CURRENCY. Annual Report of the Comptroller of the Currency. (1907). Government Printing Office, Washington, DC.

Philler v. Patterson I68 Pa 468 (I895).

PHILLIPS, R. (2003). Coping with financial catastrophe: the San Francisco clearinghouse during the earthquake of 1906. Research in Economic History, 2I, pp. 79-104.

RICHARDSON, G. (2007). The check is in the mail: correspondent clearing and the collapse of the banking system, I930 to I933. Journal of Economic History, 67, pp. 643-7I.

SPRAGUE, O. M. W. (I9I0). History of Crises under the National Banking System. Fairfield, NJ: Augustus M. Kelley Publishers. Reprint, I977.

SWANSON, W. (I908). The crisis of I 860 and the first issue of clearing-house loan certificates: II. Journal of Political Economy, I6, pp. 2 I2-26.

TALLMAN, E. and MOEN, J. (2OI2). Liquidity creation without a central bank: clearing house loan certificates in the banking panic of 1907. Journal of Financial Stability, 8, pp. 277-9I.

TIMBERLAKE, R. H. (I984). The central banking role of clearinghouse associations. Journal of Money, Credit, and Banking, I6, pp. I-I 5 .

SQUIRE, N. (1888). The New York Clearing House: Its Methods and Systems. New York: Arthur and Bonnell.

WEBER, W. (2OI2). Clearing arrangements in the United States before the Federal Reserve system. Federal Reserve Bank of Minneapolis Working Paper 695.

WICKER, E. (2000). Banking Panics of the Gilded Age. Cambridge: Cambridge University Press.

Yardley v. Philler I67 U.S. 334 (I897). 